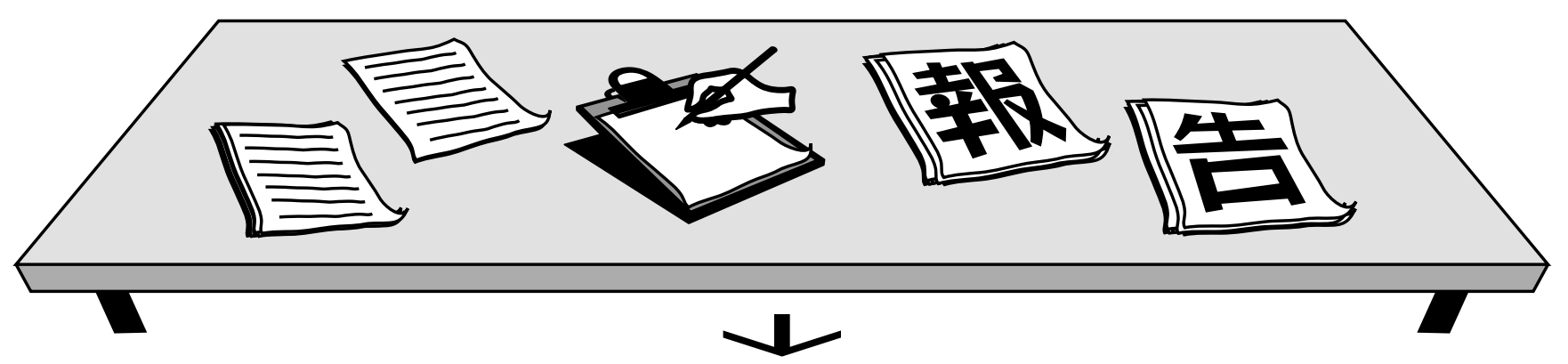

\title{
2012 年映像情報メデイア学会年次大会
}

\author{
(正会員) 滝嶋 康 弘 $^{\dagger}$
}

\section{1.まえがき}

2012 年の年次大会が，8月 29 日〜 31 日の 3 日間，広島市 立大学で開催された. 一般講演 197 件, シンポジウム講演 10 件, 公開市民講座 1 課題, 公開講演会 1 課題, 共催講演 会 1 件, 講習会 3 課題, デモ展示 11 件, 延べ参加者 1,006 名 と，過去 5 年間において，最大規模となった.

今大会の特徴として, より先端性の高い技術の発表を促 進するため, 時流に合ったテーマを設定したテーマ講演を 7 部門配置し, さらにインタラクティブな情報交換のため のデモセッションや技術習得のための講習会を実施して, より体験価值の高い大会となった。

\section{2. 年次大会の構成}

一般講演 25 部門，シンポジウム 2 セッションなど， 3 日 間とも午前と午後に発表が 6 会場で行われた。また， 2 日 目午後には市民公開講座と公開講演会が開催された。

公開講演終了後, 表彰式が執り行われた. 昨年度の年次 大会または冬季大会で優秀な発表を行った若手研究者 5 名 が鈴木記念奨励賞を受賞し, 小野寺会長から賞状と賞牌が 贈呈された. 次いで, 昨年度の冬季大会で優秀な発表を行 った学生 5 名が学生優秀発表賞を受賞し, 藤沢副会長・年 次大会実行委員長から賞状と賞牌が贈呈された。

引き続き，小野寺会長開会挨拶，山内中国支部長挨拶， 会場を提供いただいた広島市立大学浅田学長のご挨拶に続 き, 藤沢副会長の乾杯の発声で懇親会が開始された. 参加 者は 81 名にのぼり, 研究者同士, 講演者と聴講者, 若手か らシニア会員までが交流する大変有意義な場となり, 伊東 次期会長による閉会の挨拶まで，極めて盛況な会であった。

\section{3. 講演の概要*}

\section{1 一般講演}

第1 部門「カメラ位置姿勢推定のための映像処理技術」

発表 4 件, 参加者 38 名. 推定精度向上のための特徵抽出

* 参加者数は開始数分後における事務局計測值であり, 時間変動あり.

$\dagger$ 株式会社 KDDI研究所/調查担当理事

$1062(100)$
を中心に発表があった. 具体的には, 視点の情報を利用し た2D-3Dマッチング，基準マーカから算出されたホモグラ フィの他マーカ射影画像との整合性による較正法, SURF のオリエンテーション情報による自然特徵点の対応付け, MEMSセンサとPIVによる画像処理でカメラの位置姿勢情 報を獲得する手法などの発表があった。

\section{第2部門「VR関連技術とその応用」}

発表7件, 参加者 41 名. 映像に対応したhaptic 情報 (力感 フィードバック) 提示, AR 分野から空間内の物体への映像 提示, スポーツスタジアムを対象とした自由視点映像, VR を利用した吹き矢, 非固定カメラでのオブジェクト領域の 抽出, オブジェクト追跡・分離によるオクルージョン対応 などの提案があった，立ち見がでるほど盛況であった。

\section{第3部門「画像符号化」}

発表 9 件, 参加者 25 名. 階調削減・復元を用いた符号化, チャネル間符号量制御, 時空間 - 色空間統合予測符号化, 動き補償と色信号間予測に基づいた可逆符号化，再帰型イ ントラ予測の改善, HEVC符号化改善, 時空間解像度の主 観画質などの発表があった。信号処理を利用した符号化で, 低ビットレート時に, 従来の JPEGより高圧縮符号化の可 能性を示した発表が興味深かった. HEVC改善とALFフ イル夕数削減は, 規格化が大いに期待される.

\section{第4部門【テーマ講演】「携帯情報端末・スマートフォン 応用」}

発表 5 件, 参加者 21 名. 携帯端末の応用事例として, 出 欠管理や学習支援など実用的な講演がある一方で, アニメ ーション動画プレーヤなど, 今後成長が期待される技術分 野の講演もあり，本テーマへの関心がうかがえた。また， 障害者の支援に関する講演もあり, 携帯情報端末が持つ幅 広い応用可能性を再確認できた. 午前ながら多くの参加者 があり，導入コストなど実用化を見据えた議論や，評価結 果の妥当性についてなど忌憚のない意見交換が行われた.

第 5 部門「放送方式」

発表 10 件, 参加者 31 名. サイマル方式のリパック（地デ ジ放送周波数の移行) に貢献したワンセグノイズ付加, 放 送波伝搬特性, 船舶での放送波受信, 超遅延波存在下での 


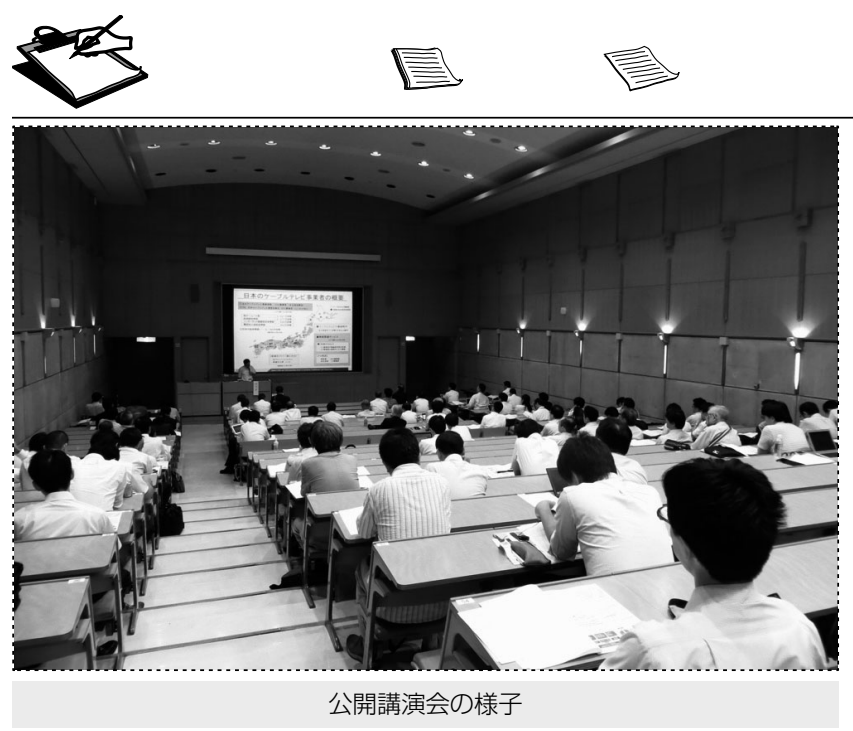

妨害波除去，エリア放送に向けたチャネルフィルタの開発， 超低レベル ISDB-T信号の検出装置の野外検証, デジタル 放送で現行スクランブル方式と新方式の並行運用, B-CAS カードの改窟による有料放送不正視聴に関する考察と多岐 にわたり, 学生による研究発表も積極的 (4件) であった.

\section{第6部門「放送現業」}

発表 5 件, 参加者 31 名. 映像アーカイブ用メタデータ入 力の効率化, 限定された周波数帯域での伝送補完を目的と した無線LAN伝送の安定化, バーチャルCGにおけるカメ ラ位置情報の精度向上, 視聴者が撮影した映像など非 HD 品質映像を番組に用いるための高画質変換, LED照明機器 の開発など, 番組制作上, 興味深く, 更なる番組品質向上 に向けた研究開発の発表が行われた.

\section{第7部門【テーマ講演】「質感知覚と映像表現・メディア} 処理」

発表 7 件, 参加者 39 名. 工学的な質感研究の最新動向に 関する特別講演に始まり，ノイズを考慮した鏡面反射の分 離, 色情報の野菜鮮度に与える影響, 高解像度感の特性に コントラストの低さが寄与するという直感にやや反する研 究, ノイズ成分の画像解像度知覚に対する寄与, 質感記憶 に関して必ずしも実物と思い描く質感が一致しないという 知見等, 興味深い発表が多数あった. 終始立ち席が出るほ ど盛況で, 質感研究に対する関心の高さが感じられた。

第8部門「コンピュータビジョン・ヒューマンインタフェ

$$
\text { ース,その他」 }
$$

発表 11 件, 参加者 24 名. 光源推定, 被写体領域抽出, 物体認識, パノラマ画像, 顔表情認識, CG 制作, VR, イ ンタラクティブコンテンツなどに関わる発表があった. 座 長からの質問が必要ない発表も多々あり, 活発な質疑が行 われた。

第9部門「ヒューマンインフォメーション」

発表 14 件, 参加者 24 名. 特徵解析による病理画像や顔画 像の識別, 視線検出, 検索やコンテンツ制作のコンピュー 夕による知的支援, コンテンツ自動生成システムの主観評 価, 没入型ディスプレイの学習コンテンツへの応用, シミ ユレータ酔の抑制に関する報告などがあり, 個人の嗜好や
経験の差異による意見の相違も見られ，人間系の評価の難 しさが議論された. また, 従来技術との比較方法に対する 指摘, 実験システムの仕様の確認, 当該分野の歴史的背景 を踏まえた質問やコメント等あり, 活発に議論された.

第 10 部門【テーマ講演】「ァイルベース制作・送出シス

$$
\text { テムとメタデータ制作」 }
$$

発表7件, 参加者 20 名. ファイルベース制作・送出, メ タデータ制作・活用のシステムの発表が行われた. システ ム導入例, 関連する規格, 将来展望について紹介された. 現在, 多くの放送局で導入が進められている注目の内容で かつ具体的な内容であったため, 多くの参加者が集まり, 質疑時間が不足するほど活発な質疑が行われた.

第11部門「コンシューマエレクトロニクスおよびマルチ

$$
\text { メディアストレージ」 }
$$

発表 10 件, 参加者 16 名. ネットワーク対応テレビ, 次 世代映像記録，家電用マイコンの応用システムなどが発表 された，次世代映像記録については，従来のホログラム方 式に加え, 磁性細線を使ったメカレスの垂直磁気記録の要 素技術などが発表された. 非常時に視聴者に適切な情報を 報知するしくみの報告では, 特に活発な質問がなされ, 震 災後の安全・安心への関心の高まりがうかがえる。

第12部門【テーマ講演】 「HEVC符号化」

発表5件, 参加者 20 名. 標準化作業中の HEVCに対して, 符号化性能改善や高速化アルゴリズム, H.264からのトラ ンスコードが提案された。 またスーパーハイビジョンでの HEVCとH.264との性能比較評価結果が報告された。各講 演に多数の質疑があり, 関心の高さがうかがえた.

第13部門「CGモデリング＆レンダリング」

発表 8 件, 参加者 25 名. CG モデリングとレンダリング に加え, CG 画像生成における最適視点の決定手法や, CG 画像からの散乱特性の推定など, CG 関連分野の多岐にわ たる内容であった. 助言を含めた活発な討論が行われた.

\section{第14 部門「立体映像技術」}

発表 8 件, 参加者 17 名. 立体映像の安全性，ステレオ映 像や光線空間の生成・取得，立体表示用の新しいデバイス 等幅広い分野からの講演があり, 映像安全性に関わる知見 が深まりつつあることが感じられた。また，ホログラム用 のスピン注入を用いた空間光変調器の開発など新しい試み も紹介され，参加者から大きな関心が寄せられた。

\section{第15部門「情報ディスプレイ」}

発表 10 件, 参加者 23 名. 液晶テレビへの適用で注目さ れている酸化物半導体 (IGZO) に関して, フレキシブルデ イスプレイへの応用を目指した研究発表が行われた。 IGZOは, 高精細化や大画面化に適した移動度の高い材料 であり，基礎特性についても活発に議論された。また，液 晶ディスプレイの高色域化に関して, 新たな光源による表 現能力向上の可能性や課題に関する意見が交わされた.

第16部門【テーマ講演】「放送通信連携」

発表 7 件, 参加者 29 名. SNS 連携による番組の付加価值 


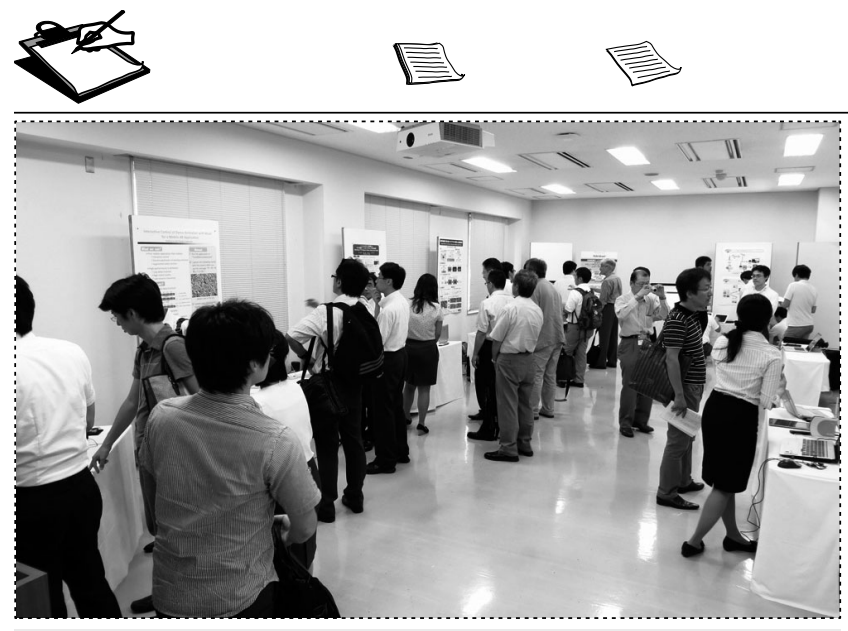

デモセッション

向上, 放送波でのIPパケット通信, ターゲッティング番組 宣伝，手話通訳，アプリケーション認証・同期，ネット情 報からCGによるニュース番組の自動生成など, 今後のテ レビ放送の可能性を探る興味深い内容であった。いずれも 積極的な質疑があり，活発なセッションであった.

第17部門「情報センシング (1)」

発表 4 件, 参加者 19 名. マルチアパーチャシステムを用 いたノイズ低減, 撮像面の分割とパラメータ制御による撮 像性能向上型イメージセンサ, TOF 画像距離センサや蛍光 寿命センサへの応用を目指した高時間分解能の電荷変調画 素構造, 広ダイナミックレンジ合成画像の客観評価のため の指標值などの発表があった.

第18 部門【テーマ講演】人にやさしい情報メディア技術」 発表 6 件, 参加者 13 名. 視聴覚障害者や子供 ·お年寄 り・外国人など, 情報弱者サポート技術が発表された. 色 覚障害者の見えをシミュレートし, 健常者の印象を損なわ ずに，色覚障害者にとって適切なコンテンツ制作を実現す る手法は, 多方面の応用が期待できる. 人を中心とした技 術に密に関わる研究者が集まり, 活発な議論が行われた.

第19部門【テーマ講演】科学技術のフロンティアを切り

拓くイメージセンサ技術」

発表 8 件, 参加者 29 名. TOF 距離画像センサの距離分解 能向上, 多層の微細メタルグリッドを形成した偏光子搭載 イメージセンサ, 脳神経活動計測用イメージセンサでの無 線伝送実験, 薄型化ニードル型CMOSイメージセンサ, 3,300 万画素 $120 \mathrm{~Hz}$ 動作の 2 段サイクリック ADCの低消費 電力設計, 小型カメラヘッド, 高感度な科学技術用超高速 度撮像デバイス, 毎秒 1,000 万コマ以上撮影可能な CMOS イメージセンサなど, いずれも興味深い発表であった。

\section{第20 部門「無線光伝送」}

発表 11 件, 参加者 18 名. 大容量 - 低遅延伝送の研究報 告 (ラジオマイク, SHV 無線伝送, STBC伝送システム, 偏波 MIMO 超多值OFDM, TSMFを拡張した多重フレーム による大容量伝送), 大学・高専の発表 (地デジアンテナ, 放送波伝搬, マイクロ波帯 LN 光変調器, マルチパス環境 CDMA 通信), その他, ケーブルテレビ伝送, ホワイトス ペース活用の災害・防災デー夕伝送等, ユニークな発表が

$1064 \quad(102)$
あった。積極的な質疑と実用化に向けた助言が多くあった。 第21 部門「映像表現技術とその応用」

発表 9 件, 参加者 34 名. 多視点撮影映像による新しい映 像表現, 点灯電球の消灯時に生じる残像の視覚特性を考慮 した表現, 被写体の顕著性から水彩画風に変換する画像生 成，3DCGの質感パラメータ，映像中の光沢部分を抽出す る手法, 超高精細コンピュータグラフィックス (ウルトラ CG）など, いずれも新規性, 時流適合性の高い発表であり, 今後の発展を大いに期待させる内容であった。早朝のセッ ションにも関わらず, 会場はほぼ満席, 立ち見が出るほど の盛況であり，この分野への関心の高さが感じられた.

\section{第22 部門「情報センシング(2)」}

発表 7 件, 参加者 17 名. カルコパイライト型半導体を用 いた，光電変換膜の信号増倍現象や空間解像度の高い放射 光を用いたX線生体顕微鏡, 空間光通信用高速レスポンス 画素構造, 曲面に書かれた文章の文字認識, 低消費電力な 冷却機構のための画素部と周辺回路部を物理的に分離した 撮像面熱分離構造, 裏面照射構造を採用してダイナミック レンジの低下を防ぎ, 高感度化を実現した超高速度 CCD の開発などの発表があり, 内容の濃い質疑が行われた.

第23 部門「画像・映像処理 (1)」

発表 9 件, 参加者 39 名. TV 正則化に基づく雑音除去, 静止画 - 動画の超解像, 手書き線画の彩色法, レンジデー 夕の補間, 映像検索システムの構築, 映像シーン検出, ピ クセルアートの拡大に関する発表があった. 前半は画像処 理の基礎で，後半は応用に関する発表が中心であった.

第24部門「デモセッション」

一般発表 6 件 + 講演会関連 2 件 + アプリ作品 5 件, 参加者 30 名. 音楽ビデオ, ダンスアニメ, ソーシャルメディアに よるテレビ番組インデキシング, サブブロックによる画像 検索, HTML5応用型スライドショー生成, 高速 ARなど の一般講演と, 公開講演関連の放送・通信連携のデモが行 われた. システム実装面でスマホ等モバイルアプリが多く, いずれもインタラクティブ性が高く, 応用イメージが説明 されていたため, 参加者にとっては有用性や独自性を体験 により理解しやすく, 活発な議論や質疑が行われた。

並行して「キネクト, スマートフォンアプリ, $\mathrm{AR}$ 等, 体 感型アプリの世界」と題して，デモ作品発表会を実施し，5 件のユニークな作品がデモされた．来場者による投票が行 われ，漫画を題材にした発表にグランプリが，タブレット 利用による患者支援の発表が準グランプリに選定され，こ れらのデモビデオは学会ホームページ上に掲載された。

第25部門「画像・映像処理 (2)」

発表 10 件, 参加者 30 名. 医療画像の特徵量抽出, クラ スタリング, 電子透かし, 画像の色合い変換やヒストグラ ム均等化, ステレオ情報に基づく再構成フィルタの発表が あった。活発な質疑や適用先のアドバイスなどがあった. 全体に，建設的なディスカッションで充実していた。

3.2 シンポジウム 
シンポジウム1「フレキシブルエレクトロニクスと映像情 報技術」

発表 5 件, 参加者 22 名. フレキシブルエレクトロニクス は，携帯端末のみならず，デイスプレイパネルの生産性向 上・大画面化にも強い影響を及ぼすと期待されている．本 シンポジウムでは，有機トランジスタによるディスプレイ の超柔軟化, 有機半導体の結晶化によるトランジスタ性能 向上, フレキシブル有機 ELの大画面化, 高耐熱性のプラ スチック基板技術, 印刷形成研究の現状と応用展開につい て, 最前線の方々に講演いただき，フレキシブル/プリン タブルエレクトロニクス分野の技術を展望できた. 材料 · デバイス・製造技術の細部はもとより, 現状の課題や今後 の見达みに関して活発な質疑がなされた。

\section{シンポジゥム $2\lceil$ 中国地方発イノベーション」}

発表 5 件，参加者 15 名. 中国地方を拠点とする起業家， MOT (技術経営) 研究者が講演を行った. 産学官連携ベー スの次世代カーエレクトロニクスへの取組みに続き, 広島 県西部(備後)を中心とする全国有数のイノベーション地区, 松江市を拠点とする OSS 企業, 備後地域で無機EL照明に 取組む中小企業, 山口を拠点とするMOT 人材育成が紹介 され, 会場はパワースポットの様相を呈していた.

\section{IEEE BTS 共催講演会}

「IEEE BTS AdCom (放送技術ソサエティ理事会)におけ る多面的国際展開活動」

参加者9名. IEEE BTS AdCom委員の平川秀治氏 (東芝) から, 理事会の活動が紹介された。 AdCom会合に参加で きる日本人は限られ, 活動内容について貴重な講演となっ た. AdCom 会合は当学会理事会や国際標準化団体である IEC 評議会などと運営方法が異なり, 会議のスタイルも米 国式である. 委員の選挙や仲間作りについて, IBCやNAB との関わりについて, 国際会議等で活躍するための心得や, 若い人に参考となる書物について, 活発な質疑が行われた.

\section{3 公開市民講演会「NHKドラマにおけるVFXの裏側」}

参加者 145 名. NHK 放送技術局制作技術センター兼沢将 人氏より，2012年の NHK 大河ドラマ「平清盛」の舞台裏を 題材として，ドラマにおけるVFXに関して講演された. VFXは美術費, エキストラ人件費, 撮影時間短縮などコス ト削減にも大きく寄与していること, NHKではドラマ制 作に不可欠としてVFXが一層多く利用されていることな どが紹介された. 自動処理の範囲, 波の合成などの厳密さ, VFXの歴史, 現時点での大きな課題など多くの質問が行わ れ, 大変大きな関心を得た。 また, 会場の様子は, $\mathrm{NHK}$ 広島のニュースとして, 翌日報道された。

3.4 公開講演会「オープンプラットフォームによる高度 映像サービス最前線 〜「賢い」テレビが創り出す自 由な映像社会〜」

参加者 115 名. 情報の表現 ·伝送 ·利用手段の多様化と 混在が加速する中, 誰もが簡単に映像情報メディアを楽し める新たなパラダイム作りや新サービス・技術に取組んで

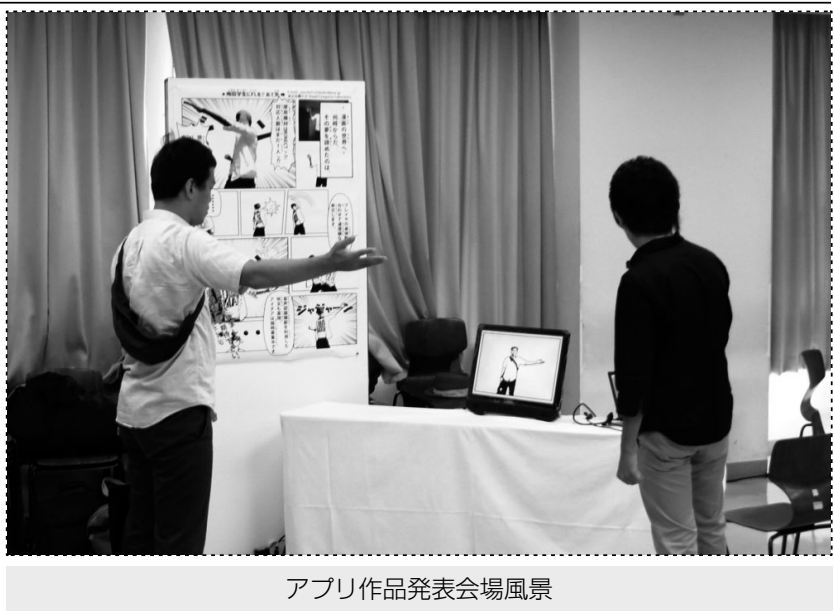

いる地上波・衛星放送, CATV, 通信サービス, モバイル 放送などの分野から 5 人のキーパーソンに，映像情報メデ イアが「つながる時代」の生活をどう変えるのか, わかりや すく解説いただいた。時間制約から最小限ではあったが, 標準化や利用シーンに関する活発な質疑があった.

\section{5 講習会}

モバイルコンテンツの先端技術で簡易アプリを製作する 実践的講習会 3 件：Android 開発講習会 (参加者 23 名), $\mathrm{AR}$ コンテンツ開発講習会 (参加者 9 名)，初心者向けモバ イルアプリ講習会 (参加者 9 名) が行われた。

\section{4. むすび}

今大会では，急速に進化する映像情報メディアに関する 研究開発のスタイルに適合した機会を提供するため，時流 に合ったテーマ講演，実践的講習会，インタラクティブに 触れられるデモセッションなど，高い体験価值を具体化す る企画を多く実施し，参加者からは好評を得られた。本大 会が，年間最大イベントの年次大会が研究者や会員の交流 を一層促進する場となる契機になれば幸いである.

末筆ながら，すべての関係者，特に部門運営と進行にご 尽力頂いた幹事, 座長, 司会者, 中国支部の方々, 講演を 快くお引き受け頂いたシンポジウムや公開講演会の講演者 の方々，年次大会の企画を熱心にご検討・提案頂いた実行 委員や理事の方々, 実利性・快適性ほかあらゆる点ですば らしい会場をご提供頂いた広島市立大学の関係者皆様，そ して優れた発表と活発な討論で大会を盛り上げて頂いた参 加者の皆様に，心から感謝を申し上げる.

なお本報告は，各部門の座長，司会者等から提出された 資料と報告を基に，一部引用して作成したものである.

(2012年 10 月 25 日受付)

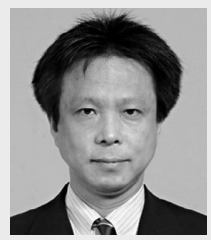

滝嶋 康弘 1986年, 東京大学工学部電気工学科 卒業. 1988 年, 同大学大学院電子工学専攻修士課程修 了. 同年，国際電信電話 (株) (現 KDDI (株)) 入社. 現 在, (株) KDDI研究所ヒューマンコミュニケーション 部門部門長. 動画像の符号化方式，動画通信システム， 情報理論の研究・開発に従事. 工学博士. 正会員. 